\title{
Purification of Aqueous Solution from Ni (II) Ions Using Commercial and Bitter Orange Leaves Activated Charcoal
}

\author{
Areej. A. Jarullah*, Mahasin. F. Alias** and Karim. H. Hassan* \\ * Department of Chemistry, College of Science, University of Diyala, Iraq. \\ ** Department of Chemistry, College of Science for Women, University of Baghdad, Iraq.
}

\begin{abstract}
The purification of diluted aqueous solution from toxic Ni (II) ion was investigated using commercial and bitter orange leaves activated charcoal as adsorbents through batch method. The contact times between the adsorbents and adsorbate at $298 \mathrm{~K}$ and $\mathrm{pH}$ of 5 were studied. The percentage metal removal approached equilibrium within 75 min on Commercial and 90 min on prepared charcoal surfaces. The experimental data of the metal removal equilibrium were correlated by either the Langmuir or Freundlich equations. Results indicate that the Langmuir model gave a better fit to the experimental data than the Freundlich equation. Kinetic processes of $\mathrm{Ni}^{2+}$ adsorption on Commercial and prepared charcoal were described by applying pseudo-first-order and pseudosecond-order rate equations which that the adsorption process obey pseudo-second-order rate equation.
\end{abstract}

Keywords: Activated charcoal (AC); Nickel ion; Langmuir isotherm; Freundlich isotherm.

\section{Introduction}

Heavy metals are well identified contaminants for public health, plants and animals because of its toxicity [1]. Toxic heavy metals a part from being hazardous for living organism, when exceed the specific limits, have accumulation characteristic in nature as they cannot be biodegraded, causing health problems in animals, plants and human beings [2,3]. Inorganic effluent from the industries contains toxic metals such as $\mathrm{Ni}$, $\mathrm{Cu}, \mathrm{Zn}$ and $\mathrm{Cd}$...etc., which tend to accumulate in the food chain [4]. Because of their high solubility in the aquatic environments, heavy metal can be adsorbed by living organism. Once they enter the food chain large concentrations of heavy metals may accumulate in the human body [5]. The increase in usage of heavy metals in industrial activities has caused the existence of them in wastewater [6]. As for most metals, the toxicity of nickel is dependent on the route of exposure and the solubility of the nickel compound [7]. Human nickel exposure originates from a variety of sources and is highly variable. It is normally present in human tissues and, under conditions of high exposure, these levels may increase significantly [8]. Human may be exposed to nickel by breathing air, drinking water, eating food or smoking cigarettes. Skin contact with nickel contaminated soil or water may also result in nickel exposure. In small quantities nickel is essential, but when the uptake is too high it can be a danger to human health [9]. The excessive exposure to nickel can lead to severe damage of lung, kidneys, skin dermatitis, and cancer [10]. In recent years, increasing awareness of the environmental impact of heavy metals has prompted a demand for the purification of industrial wastewater prior to discharge into natural waters. This has led to the introduction of more strict legislation to control water pollution [11]. Activated carbon adsorption has been a promising technique for the removal of heavy metal ions from water [12]. For examples, Kadirvelu K., et al [13] studied the adsorption of $\mathrm{Cd}^{2+}$ from aqueous solution by activated carbon prepared from coconut coirpith, Moreno J.C., et al [14] studied removal of $\mathrm{Mn}^{2+}, \mathrm{Fe}^{2+}, \mathrm{Ni}^{2+}$ and $\mathrm{Cu}^{2+}$ ions from wastewater using cow bone charcoal.

The objective of this study was to evaluate the feasibility of using the commercial and bitter orange leaves activated charcoal for the removal of nickel from aqueous solution. The adsorption process is studied from kinetic and isotherm standpoints. 


\section{Materials and Methods \\ Adsorbent}

Commercial and prepared activated charcoal were used as adsorbents in this study. The commercial activated charcoal (CAC) was supplied from the BDH, ANALAR, England. Prepared activated charcoal (PAC) was prepared from leaves of bitter orange tree (Citrus aurantium) [15]. The CAC and PAC were sieved using sieve nominal size $75 \mu \mathrm{m}$ (no.200). The adsorbents were characterized by X-ray diffraction (XRD) using instrument type BRUKER, D8 ADVANCE using $\mathrm{Cu} \mathrm{Ka}$ radiation of $1.54^{\circ} \mathrm{A}$.

\section{Adsorbate}

A standard stock solution of $\mathrm{Ni}$ (II) ion (1000 $\mathrm{mg} / \mathrm{L})$ was prepared from $\mathrm{Ni}\left(\mathrm{NO}_{3}\right)_{2} \cdot 6 \mathrm{H}_{2} \mathrm{O}$ (supplied by $\mathrm{BDH}$ chemical) in deionized water. Several concentrations (25, $50,70,85$, and $100 \mathrm{mg} / \mathrm{L}$ ) were prepared from this standard stock. Absorbance values of these solutions were measured at the specified wave length of $232 \mathrm{~nm}$.

\section{Adsorption studies}

$(25 \mathrm{ml})$ of $\mathrm{Ni}$ (II) solution of a known concentration ranged from $(25 \mathrm{mg} / \mathrm{L})$ to $(100 \mathrm{mg} / \mathrm{L})$ were added separately to volumetric flasks containing $(0.5 \mathrm{~g})$ of CAC or $(0.2 \mathrm{~g})$ of PAC, at temperature of $298 \mathrm{~K} \pm 2$ and $\mathrm{pH}$ of 5 [15], the flasks were shaken in thermostatically controlled water bath shaker at a constant speed (180 cycles per min) for the required equilibrium time. The mixtures were then separated by centrifugation at (3000 rpm) for (15min) and then filtered using a whatman No.42 filter paper.

The metal equilibrium concentrations were measured using atomic absorption spectrometer (AAS) by comparing the experimental absorbance with the calibration curve.

The adsorption capacity of adsorbent was calculated using the equation below [10]:

$Q_{e}=\frac{\left(C_{o}-C_{e}\right) \cdot V}{m}$

Where:

Qe: Adsorption capacity of the adsorbent at equilibrium time $\mathbf{t}_{\mathbf{e}}(\mathrm{mg} / \mathrm{g})$.

$\mathrm{C}_{\mathrm{o}}$ : Initial concentration of adsorbate $(\mathrm{mg} / \mathrm{L})$.
$\mathrm{C}_{\mathrm{e}}$ : Equilibrium concentration of adsorbate after adsorption has occurred $(\mathrm{mg} / \mathrm{L})$.

$\mathrm{V}$ : Volume of solution (L).

$\mathrm{m}$ : Weight of adsorbent ( $\mathrm{g})$.

\section{Results and Discussion}

X-ray diffraction (XRD) analysis of the adsorbents.

The crystalline structure of the CAC and PAC were characterized using X-ray diffractometer, and the results are shown in Fig.(1) and Fig.(2) respectively. In Fig.(1) the angles $2 \Theta$ at 26.562 (003), 42.490 (101), and 45.672 (012) are the characteristic of CAC crystal and in Fig.(2) the angles $2 \Theta$ at 26.716 (003), 43.013 (101), and 46.421 (012) are those of PAC. The diffraction data were in good agreement with the standard spectrum.

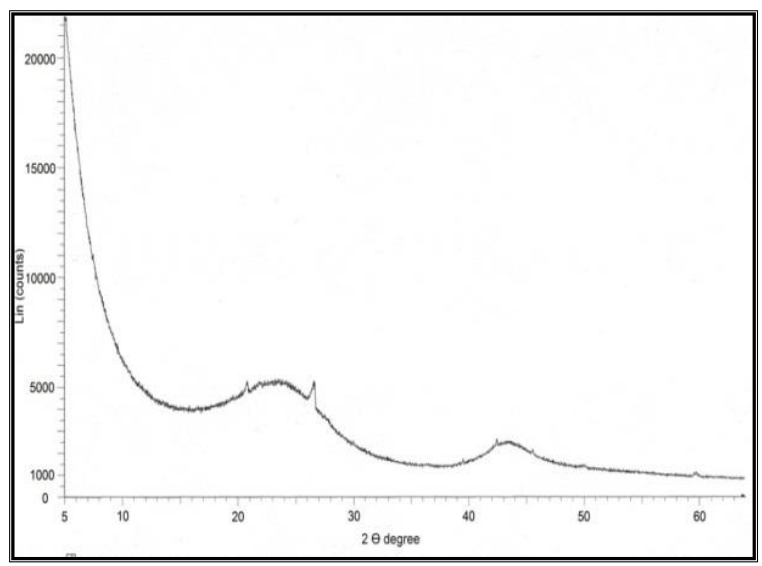

Fig. (1) X-ray diffraction analysis of commercial activated charcoal.

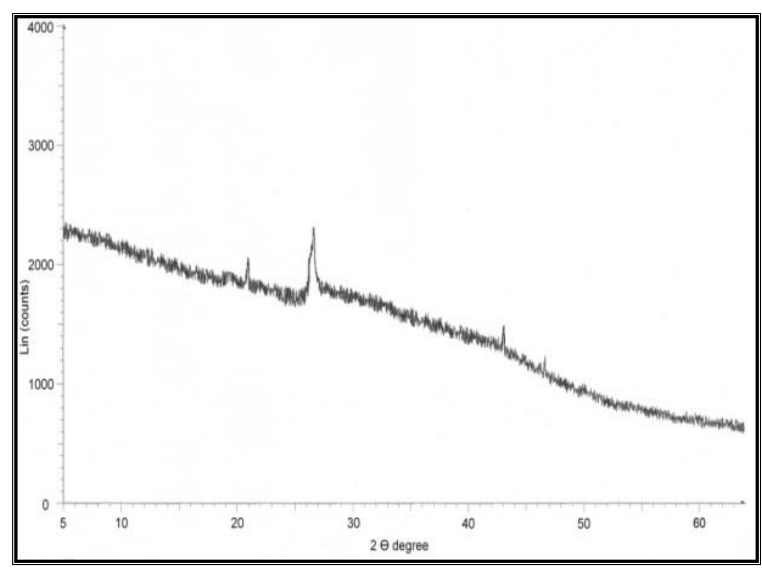

Fig.(2) X-ray diffraction analysis of bitter orange leaves activated charcoal. 


\section{Contact time of adsorption}

The contact times between the CAC and PAC with $\mathrm{Ni}$ (II) ion solution that is sufficient for the adsorption process to reach equilibrium using a fixed concentration $\left(\mathrm{C}_{\mathrm{o}}=85 \mathrm{mg} / \mathrm{L}\right)$ and $\mathrm{pH}$ of 5 at $298 \mathrm{~K}$ were studied at different periods $(10,30,45,60,75,90,120$ and 150) $\min$.

The metal removal percentage was calculated using equation (2)[16].

$$
\mathrm{R} \%=\frac{\left(\mathrm{C}_{\mathrm{o}}-\mathrm{C}_{\mathrm{t}}\right) \cdot 100}{\mathrm{C}_{\mathrm{o}}}
$$

Where:

$\mathrm{R} \%$ : The metal removal percentage.

$\mathrm{C}_{\mathrm{o}}$ : The initial concentration of metal (mg/L).

$\mathrm{C}_{t}$ : The residual concentration of metal after adsorption had taken place over a period of time $\mathbf{t}$ expressed as $(\mathrm{mg} / \mathrm{L})$.

The result of the effect of contact time on the adsorption of $\mathrm{Ni}$ (II) from aqueous solution is shown in Fig.(3). It was observed that the percentage metal removal increased rapidly with increase in contact time. The adsorption of $\mathrm{Ni}$ (II) ion by CAC and PAC was rapid for the first $10 \mathrm{~min}$ of contact time. The fast adsorption at the initial stage due to the initial concentration gradient between the adsorbate in solution and the number of vacant sites available on the adsorbent surfaces at the beginning. The progressive increase in adsorption and consequently the attainment of equilibrium adsorption may be due to limited mass transfer of the adsorbate molecules from the bulk liquid to the surface of adsorbent [1618]. The time required for (Ni (II)-CAC) and (Ni (II)-PAC) systems to attain equilibrium to be 75, and $90 \mathrm{~min}$ respectively.

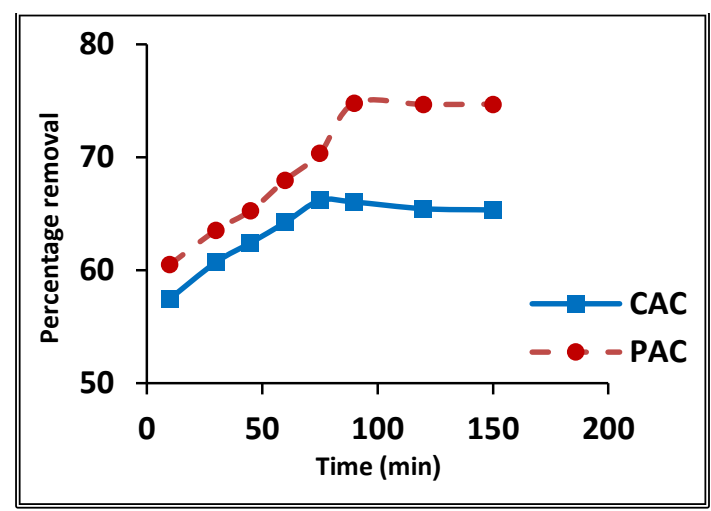

Fig.(3) Effect of contact time on adsorption of $\mathrm{Ni}(\mathrm{II})$ ion $\left(\mathrm{C}_{\mathrm{o}}=85 \mathrm{mg} / \mathrm{L}\right)$ on $\mathrm{CAC}$ and PAC Surfaces.

Kinetic study of adsorption $\left(\mathrm{Ni}^{2+}\right)$ by $\mathrm{CAC}$ and PAC surfaces.

Kinetic studies were carried out with $(0.5 \mathrm{~g})$ of commercial activated carbon and $(0.2 \mathrm{~g})$ of prepared activated carbon at $298 \mathrm{~K}$ and $\mathrm{pH}$ of 5 from 10 to $150 \mathrm{~min}$. The adsorption increased rapidly and reach equilibrium within $75 \mathrm{~min}$ for $\mathrm{CAC}$ and $90 \mathrm{~min}$ for PAC. The order of adsorbate adsorbent interaction has been described using various kinetic models. Table (1) show the kinetic data for adsorption of $\mathrm{Ni}(\mathrm{II})$ ion on CAC and PAC surfaces which is being used in pseudo-first and pseudo-second order model.

Pseudo-first order rate expression, popularly known as the lagergren equation, is generally described by the following equation[14].

$\ln \left(Q_{e}-Q_{t}\right)=\ln Q_{e}-K_{1} t$

Where:

$\mathrm{Q}_{\mathrm{e}}$ is the amount of the metal ions adsorbed at equilibrium per unit weight of sorbent $\left(\mathrm{mg} \cdot \mathrm{g}^{-1}\right)$.

$\mathrm{Q}_{t}$ is the amount of the metal ions adsorbed at any time $\left(\mathrm{mg} \cdot \mathrm{g}^{-1}\right)$.

$\mathrm{K}_{1}$ is the rate constant $\left(\mathrm{min}^{-1}\right)$.

The slope and intercept of plots of $\ln \left(\mathrm{Q}_{e^{-}}\right.$ $\mathrm{Q}_{\mathrm{t}}$ ) versus $\mathrm{t}$ in Fig. (4) were used to determine the first order rate constant $\mathrm{K}_{1}$ and equilibrium adsorption capacity Qe. Pseudo first order model is used to described the reversibility of the equilibrium between liquid and solid phase [10].

The adsorption data was also analyzed in term of the pseudo-second order given by [5]:

$\frac{t}{Q_{t}}=\frac{1}{K_{2} Q_{e}^{2}}+\frac{1}{Q_{e}} t$

Where:

$\mathrm{K}_{2}$ is the equilibrium rate constant of pseudosecond order adsorption (g/mg. min.)

The plot of $\frac{\boldsymbol{t}}{\boldsymbol{Q}_{\boldsymbol{t}}}$ against $\mathrm{t}$ gives a linear relationship, and $\mathrm{K}_{2}$ and $\mathrm{Q}_{\mathrm{e}}$ can be calculated from the slope and intercept of the line in Fig. (5). 
Results in Table (2) shows the kinetic rate constants, correlation coefficient $\mathrm{R}^{2}$, and calculated equilibrium sorption capacity $\left(\mathrm{Q}_{\mathrm{e}}\right)$ of $\mathrm{Ni}$ (II) ions on CAC and PAC surfaces. From the results, it can be concluded that pseudo - second- order equation provides the best correlation coefficient $\mathrm{R}^{2}$ and agreement between the calculated equilibrium sorption capacity $\left(\mathrm{Q}_{\mathrm{e}}\right)$ and experimental $\left(\mathrm{Q}_{\mathrm{e}}\right)$ values. The results suggest that the pseudo - second order sorption mechanism is predominant $[5,10,19]$.

Table (1)

Kinetic data for adsorption of $\mathrm{Ni}(\mathrm{II})$ ion on $C A C$ and PAC surfaces.

\begin{tabular}{|c|c|c|c|}
\hline \multirow{3}{*}{$\begin{array}{l}\text { Time } \\
\text { min }\end{array}$} & \multicolumn{3}{|c|}{$C A C$} \\
\hline & \multicolumn{3}{|c|}{$Q e=2.8127(\mathrm{mg} / \mathrm{g})$} \\
\hline & $\begin{array}{c}Q_{t} \\
m g / g\end{array}$ & $\begin{array}{c}\ln \left(Q_{e^{-}}\right. \\
\left.Q_{t}\right)\end{array}$ & $\begin{array}{c}t / Q_{t} \\
\mathrm{~min} / \mathrm{mg} . \mathrm{g}^{-1}\end{array}$ \\
\hline 10 & 2.4424 & -0.9934 & 4.0943 \\
\hline 30 & 2.5801 & -1.4584 & 11.6274 \\
\hline 45 & 2.6533 & -1.8363 & 16.9600 \\
\hline 60 & 2.7301 & -2.4937 & 21.9772 \\
\hline \multirow{3}{*}{$\begin{array}{l}\text { Time } \\
\text { min }\end{array}$} & \multicolumn{3}{|c|}{$P A C$} \\
\hline & \multicolumn{3}{|c|}{$Q e=7.9457(\mathrm{mg} / \mathrm{g})$} \\
\hline & $\underset{m g / g}{Q_{t}}$ & $\begin{array}{c}\ln \left(Q_{e^{-}}\right. \\
\left.Q_{t}\right)\end{array}$ & $\begin{array}{c}t / Q_{t} \\
\min / m g . g^{-1}\end{array}$ \\
\hline 10 & 6.4292 & 0.4164 & 1.5554 \\
\hline 30 & 6.7523 & 0.1768 & 4.4429 \\
\hline 45 & 6.9363 & 0.0093 & 6.4876 \\
\hline 60 & 7.2228 & -0.3244 & 8.3070 \\
\hline$\overline{75}$ & 7.4764 & -0.7565 & 10.0315 \\
\hline
\end{tabular}

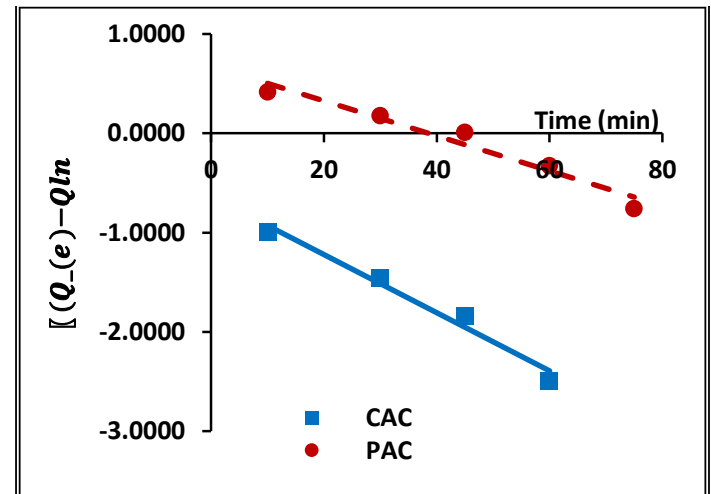

Fig.(4) Pseudo - First order kinetic plot for the adsorption of $\mathrm{Ni}$ (II) ion from aqueous solution on CAC and PAC surfaces.

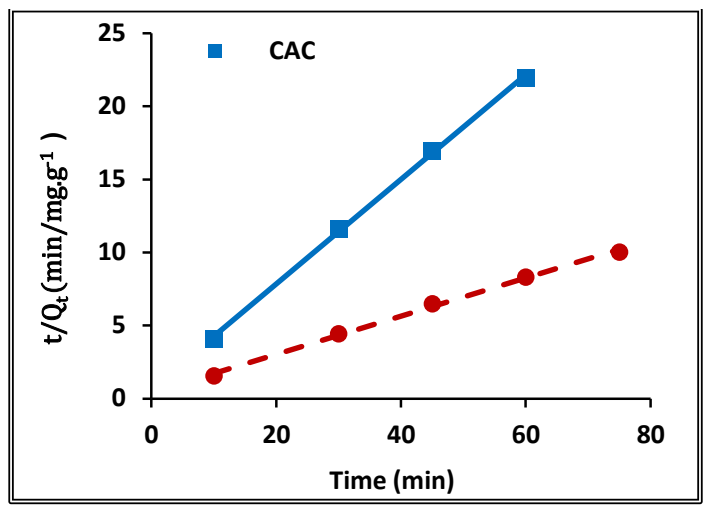

Fig. (5) Pseudo - Second order kinetic plot for the adsorption of $\mathrm{Ni}$ (II) ion from aqueous solution on CAC and PAC surfaces.

Table (2)

The calculated parameters of the PseudoFirst order \& Pseudo-Second order kinetic models of $\left(\mathrm{Ni}^{2+}\right)$ ions from $\mathrm{CAC} \& \mathrm{PAC}$ surfaces.

\begin{tabular}{|c|c|c|c|}
\hline \multirow[b]{2}{*}{$A C$} & \multicolumn{3}{|c|}{ Pseudo - First order } \\
\hline & $\begin{array}{c}K_{1} \\
\text { min }^{-1}\end{array}$ & $\begin{array}{c}Q_{e} \\
m g / g\end{array}$ & $R^{2}$ \\
\hline CAC & 0.0293 & 0.5307 & 0.9741 \\
\hline PAC & 0.0176 & 1.9724 & 0.9531 \\
\hline \multirow[b]{2}{*}{$A C$} & \multicolumn{3}{|c|}{ Pseudo - Second order } \\
\hline & $\begin{array}{c}K_{2} \\
\text { g/mg.min }\end{array}$ & $\begin{array}{c}Q_{e} \\
m g / g\end{array}$ & $R^{2}$ \\
\hline CAC & 0.1853 & 2.7925 & 0.9992 \\
\hline PAC & 0.0373 & 7.6628 & 0.9974 \\
\hline
\end{tabular}

\section{The adsorption isotherm}

Adsorption of $\mathrm{Ni}$ (II) ion from an aqueous solution on CAC and PAC was studied at four temperatures $(298,313,333$, and 353$) \mathrm{K}$ and $\mathrm{pH}$ of 5 as show in Table (3).

Adsorption isotherms are mathematical models that describe the distribution of the adsorbate species among liquid and adsorbent, based on a set of assumption that are mainly related to the heterogeneity/homogeneity of adsorbent, the type of coverage and possibility of interaction between the adsorbate species. Adsorption data are usually described by adsorption isotherms, such as Langmuir and Freundlich isotherms. These isotherm relate metal uptake per unit mass of adsorbent $\mathrm{Q}_{\mathrm{e}}$ to the equilibrium adsorbate concentration in the bulk fluid face $\mathrm{C}_{\mathrm{e}}[20]$.

The quantities adsorbed $\mathrm{Q}_{\mathrm{e}}$ were plotted versus equilibrium concentration $C_{e}$ to obtain 
the general case of the adsorption isotherms and shown in Fig.(6) and (7) for the prepared and commercial activated carbon at different temperatures.

Table (3)

Data of Ni(II) ion uptake by the CAC \& PAC surfaces at different temperatures and pH of 5.

\begin{tabular}{|c|c|c|c|c|c|c|c|c|c|}
\hline \multirow[b]{2}{*}{$\mathcal{U}$} & \multirow{2}{*}{$\begin{array}{c}C_{o} \\
m g / L\end{array}$} & \multicolumn{2}{|c|}{$298 \mathrm{~K}$} & \multicolumn{2}{|c|}{$313 \mathrm{~K}$} & \multicolumn{2}{|c|}{$333 \mathrm{~K}$} & \multicolumn{2}{|c|}{$353 \mathrm{~K}$} \\
\hline & & $\begin{array}{c}C_{e} \\
m g / L \\
\end{array}$ & $\begin{array}{c}Q_{e} \\
m g / g\end{array}$ & $\begin{array}{c}C_{e} \\
m g / L \\
\end{array}$ & $Q_{e} \mathrm{mg} / \mathrm{g}$ & $C_{e} m g / L$ & $Q_{e} m g / g$ & $C_{e} m g / L$ & $Q_{e} m g / g$ \\
\hline \multirow{5}{*}{ త্ } & 25 & 3.5471 & 1.0726 & 5.5283 & 0.9735 & 7.3396 & 0.8830 & 8.8773 & 0.8061 \\
\hline & 50 & 10.9245 & 1.9537 & 16.5094 & 1.6745 & 19.2264 & 1.5386 & 21.9150 & 1.4042 \\
\hline & 70 & 18.9339 & 2.5533 & 27.9811 & 2.1009 & 30.7735 & 1.9613 & 35.0188 & 1.7490 \\
\hline & 85 & 28.7452 & 2.8127 & 38.0943 & 2.3452 & 42.0094 & 2.1495 & 45.9433 & 1.9528 \\
\hline & 100 & 38.0377 & 3.0981 & 50.3396 & 2.4830 & 54.1981 & 2.2900 & 60.3867 & 1.9806 \\
\hline \multirow{5}{*}{$\vec{Z}$} & 25 & 1.2264 & 2.9717 & 2.0283 & 2.8714 & 3.0471 & 2.7441 & 4.5754 & 2.5530 \\
\hline & 50 & 5.4150 & 5.5731 & 6.9528 & 5.3809 & 9.7924 & 5.0259 & 12.8018 & 4.6497 \\
\hline & 70 & 12.6037 & 7.1745 & 16.6886 & 6.6639 & 19.4811 & 6.3148 & 20.9716 & 6.1285 \\
\hline & 85 & 21.4339 & 7.9457 & 25.2924 & 7.4634 & 29.3018 & 6.9622 & 32.7264 & 6.5342 \\
\hline & 100 & 29.2075 & 8.8490 & 33.3396 & 8.3325 & 39.5377 & 7.5577 & 42.7924 & 7.1509 \\
\hline
\end{tabular}

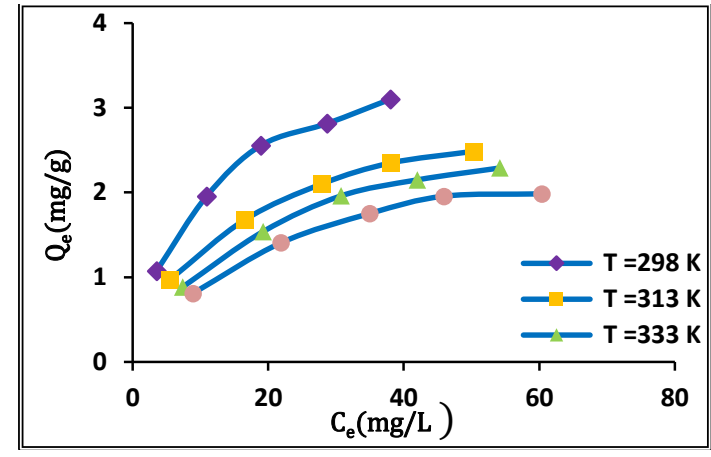

Fig. (6) Adsorption isotherm of Ni (II) ion on CAC surface at different temperatures.

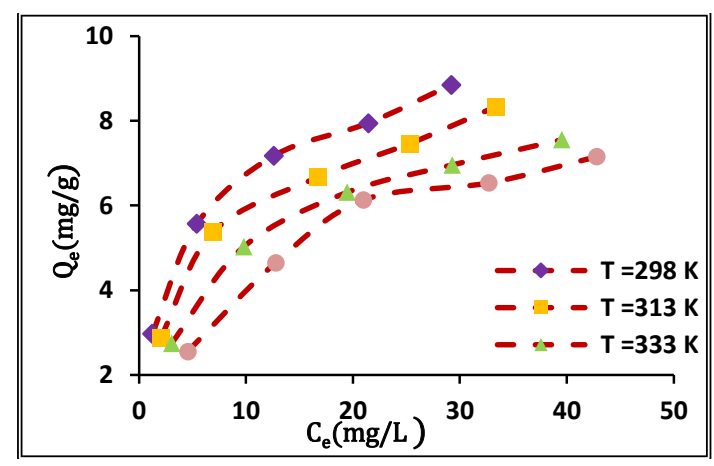

Fig. (7) Adsorption isotherm of Ni (II) ion on PAC surface at different temperatures.

\section{The Langmuir isotherm}

Langmuir isotherm describes monolayer adsorption based on assumption that all the adsorption sites have equal adsorbate affinity (the surface is homogeneous) and that adsorption at one site does not affect adsorption at an adjacent site [21,22].

In the case of adsorption from the solution, Langmuir isotherms could be fitted by the equation $[11,23]$ :-

$Q_{e}=\frac{a b C_{e}}{1+b C_{e}}$

Where:-

$\mathrm{Q}_{\mathrm{e}}$ : The quantity adsorbed at equilibrium in $(\mathrm{mg} / \mathrm{g})$.

$\mathrm{C}_{\mathrm{e}}$ : The equilibrium concentration of adsorbate in ( $\mathrm{mg} / \mathrm{L})$.

$\mathrm{a}$ and $\mathrm{b}$ : $\mathbf{a}$ is a Langmuir constant which is a measure of monolayer adsorption capacity in $(\mathrm{mg} / \mathrm{g})$ and $\mathbf{b}$ is also Langmuir constant in $(\mathrm{L} / \mathrm{mg})$

Also, we can write the linear form of this equation as :-

$\frac{\mathrm{C}_{e}}{\mathrm{Q}_{e}}=\frac{1}{\mathrm{ab}}+\frac{\mathrm{C}_{e}}{\mathrm{a}}$

This form can be used as a linearization of experimental data by plotting $\mathrm{C}_{e} / \mathrm{Q}_{e}$ against $\mathrm{C}_{e}$ as shown in Fig.(8) and (9). The Langmuir's constants (a) and (b) can be evaluated from the slope (1/a) and intercept $(1 / a b)$ of the linear equation [11, 23], and the results are shown in Table (4). 


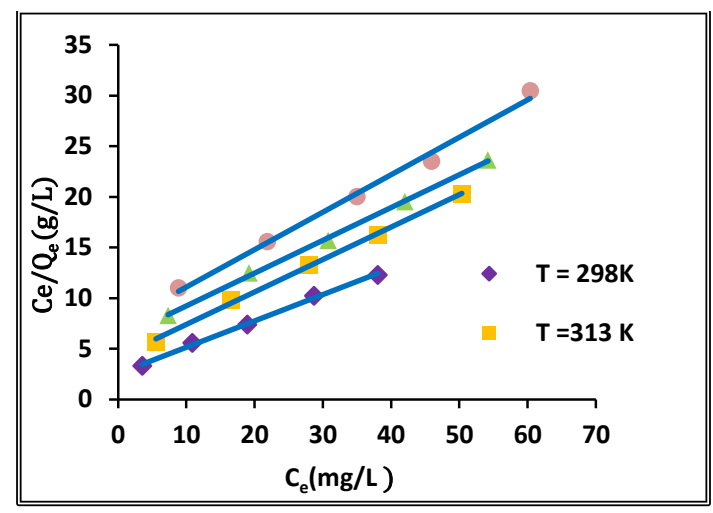

Fig. (8) Linear form of Langmuir isotherm of $\mathrm{Ni}$ (II) ion on CAC surface at different temperatures.

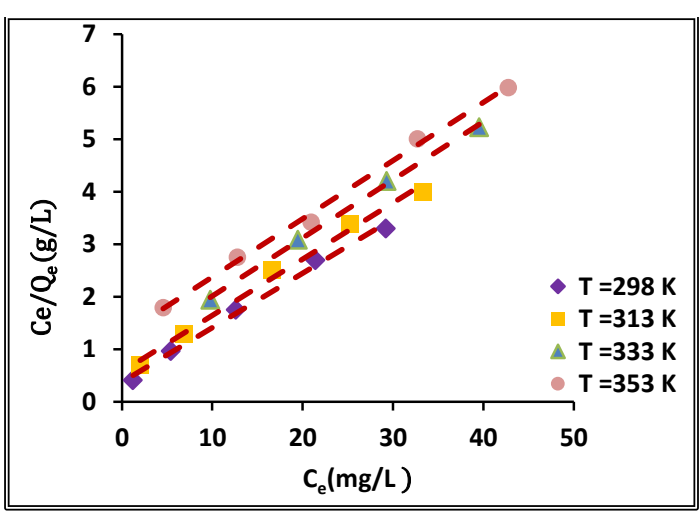

Fig. (9) Linear form of Langmuir isotherm of $\mathrm{Ni}$ (II) ion on PAC surface at different temperatures.

\section{The Freundlich isotherm}

Freundlich has proposed an empirical equation of adsorption in solution. Freundlich adsorption isotherm equation may be derived assuming a heterogeneous surface and is based on the idea that the adsorption depending on the energy of the adsorption sites [24,25]. This equation is as follows $[20,26]$ :-

$$
Q_{e}=K_{f} C_{e^{\frac{1}{n}}}
$$

Where:-

$\mathrm{Q}_{\mathrm{e}}$ : The quantity adsorbed at equilibrium in (mg/g) .

$\mathrm{C}_{\mathrm{e}}$ : The equilibrium concentration of the adsorbate in $(\mathrm{mg} / \mathrm{L})$.

$\mathrm{K}_{f}$ and $\mathrm{n}$ : The Freundlich experimental constants, $\mathbf{K}_{\boldsymbol{f}}$ and $\mathbf{n}$ are indicators of the adsorption capacity and adsorption intensity, respectively.

Taking logarithms of equation (7) we get: -

$\log Q_{e}=\log K_{f}+\frac{1}{n} \log C_{e}$
If $\log \mathrm{Q}_{\mathrm{e}}$ is plotted against $\log \mathrm{C}_{\mathrm{e}}$ a straight line should be obtained as shown in Fig. (10) and (11). The slope of the line will give the value of $1 / \mathrm{n}$ and the intercept on the $\mathrm{Y}$-axis gives the value of $\log \mathrm{K}_{f}[20,26]$ and the results are shown in Table (5).

The Freundlich isotherm is widely used but provides no information on the monolayer adsorption capacity in contrast to the Langmuir model [20].

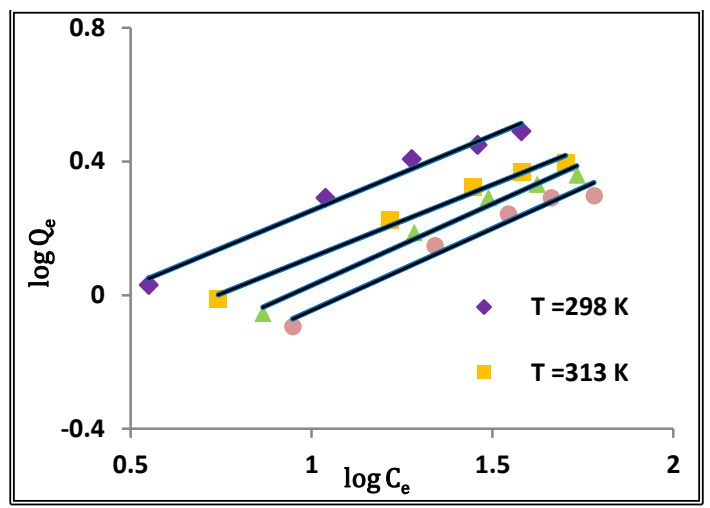

Fig. (10) Linear form of Freundlich isotherm of $\mathrm{Ni}$ (II) ion on CAC surface at different temperatures.

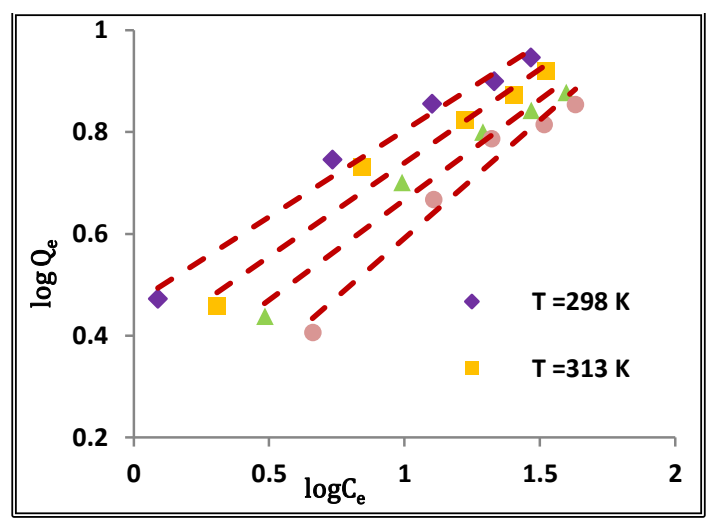

Fig. (11) Linear form of Freundlich isotherm of Ni (II) ion on PAC surface at different temperatures. 
Table (4)

Langmuir empirical constants values and the correlation coefficients for the adsorption of $\left(\mathrm{Ni}^{2+}\right)$ on $\mathrm{CAC} \& \mathrm{PAC}$ surfaces at different temperatures.

\begin{tabular}{|c|c|c|c|c|}
\hline \multirow{2}{*}{ 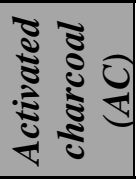 } & \multirow[b]{2}{*}{$\begin{array}{l}T \\
K\end{array}$} & \multicolumn{3}{|c|}{ Langmuir model } \\
\hline & & $\underset{(m g / g)}{a}$ & $\begin{array}{c}b \\
(L / m g)\end{array}$ & $R^{2}$ \\
\hline \multirow{4}{*}{ U̦ } & 298 & 3.8505 & 0.1014 & 0.9973 \\
\hline & 313 & 3.1250 & 0.0759 & 0.9978 \\
\hline & 333 & 3.0845 & 0.0541 & 0.9988 \\
\hline & 353 & 2.7048 & 0.0499 & 0.9930 \\
\hline \multirow{4}{*}{$e^{U}$} & 298 & 9.6618 & 0.2718 & 0.9938 \\
\hline & 313 & 9.3370 & 0.1872 & 0.9921 \\
\hline & 333 & 9.0334 & 0.1226 & 0.9986 \\
\hline & 353 & 9.0252 & 0.0872 & 0.9959 \\
\hline
\end{tabular}

Table (5)

Freundlich empirical constants values and the correlation coefficients for the adsorption of $\left(\mathrm{Ni}^{2+}\right)$ on $\mathrm{CAC} \& \mathrm{PAC}$ surfaces at different temperatures.

\begin{tabular}{|c|c|c|c|c|}
\hline \multirow{2}{*}{ 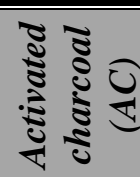 } & \multirow{2}{*}{$\begin{array}{l}T \\
K\end{array}$} & \multicolumn{3}{|c|}{ Freundlich model } \\
\hline & & $n$ & $K_{f}$ & $R^{2}$ \\
\hline \multirow{4}{*}{ Ư } & 298 & 2.2187 & 0.6331 & 0.9831 \\
\hline & 313 & 2.3009 & 0.4769 & 0.9889 \\
\hline & 333 & 2.0496 & 0.3476 & 0.9817 \\
\hline & 353 & 2.0437 & 0.2915 & 0.9676 \\
\hline \multirow{4}{*}{$\underset{L}{U}$} & 298 & 2.9446 & 2.9093 & 0.9838 \\
\hline & 313 & 2.7225 & 2.3555 & 0.9740 \\
\hline & 333 & 2.5361 & 1.8732 & 0.9755 \\
\hline & 353 & 2.1556 & 1.3418 & 0.9641 \\
\hline
\end{tabular}

As presented in Table (4) and (5), The correlation coefficients for the linear Langmuir regression fits are larger than that for the Freundlich plot, so the Langmuir model could describe well the adsorption isotherm for the uptake of $\mathrm{Ni}$ (II) ion from aqueous solution on CAC and PAC surfaces thus, indicating to the applicability of monolayer coverage of the $\mathrm{Ni}^{2+}$ ion on the surface of adsorbent [27].

\section{Conclusions}

The two adsorbent which are used in the study [commercial and prepared activated charcoal from the dry leaves of bitter orange tree (Citrus aurantium)] have a high ability for removing the $\mathrm{Ni}$ (II) ion from aqueous solutions, however, prepared activated charcoal has the highest affinity. Equilibrium data obtained for the two adsorbents were fitted to the Langmuir more than Freundlich isotherms. The Langmuir model assumes that the uptake of metal ions occurs on a homogenous surface by monolayer adsorption. Adsorption of $\mathrm{Ni}^{2+}$ obeys pseudo-second order equation with good correlation.

\section{References}

[1] Muthukrishnan, M.; Guha, B.K.; "Heavy metal separation by using surface modified nanofiltration membrane"; Desalination, 200, 351-353, 2006.

[2] Saravanan, A.; Brindha, V.; Manimekalai, R.; Krishnan, S; "An evaluation of chromium and zinc biosorption by a sea weed (Sargassum Sp.) under optimized conditions"; Indian J. Sci. Tech., 2 (1), 5356, 2009.

[3] Ong, S.; Seng, C.; Lim, P.; "kinetics of adsorption of $\mathrm{Cu}$ (II) and $\mathrm{Cd}$ (II) from aqueous solution on rice husk and modified rice husk"; J. Environ. Agric. Food Chem., 6 (2), 1764-1774, 2007.

[4] Kurniawan, T.A.; Chan, G; "physiochemical treatment techniques for wastewater laden with heavy metals"; Chem. Eng. J., 118, 83-98, 2006.

[5] Panneerselvam, P.; Bala, V.S.S.; Thiruvengadaravi, K.V.; Nandagobal, J.; Palanichamy, M.; Sivanesan, S.; "The removal of copper ions from aqueous solution using phosphoric acid modified ß-Zeolites"; Indian J. Sci. Tech., 2 (2), 6366, 2009.

[6] Oboh, I.; Aluyor, E.; Audu, T.; "Biosorption of heavy metal ions from aqueous solution using a biomaterial"; Leonardo J. Sci., 14, 58-65, 2009.

[7] Coogan, T.P.; latta, D.M.; Snow, E.T.; Costa, M.; "Toxicity and carcinogenicity of nickel compounds"; Critical Reviews in Toxicology, 19(4), 341- 384, 1989. 
[8] Chang, L.W.; "Toxicology of metals"; Lewis Publisher, New York, 1996.

[9] Cempel, M.; Nickel, G.; "Nickel: A review of its sources and environmental toxicology"; Polish J. of Environ. Stud., 15 (3), 375-382, 2006.

[10] Rozaini, C.A.; Jain, K.; Oo, C.W.; Tan, K.W.; Tan, L.S.; Azraa, A.; Tong, K.S.; "Optimization of nickel and copper ions removal by modified mangrove barks"; Int. J. Chem. Eng. Appl., 1 (1), 84-89, 2010 .

[11] Waly, T.A.; Dakroury, A.M.; El-sayed, G.O.; El-salam, S.A.; "Assessment removal of heavy metals ions from wastewater by cement kiln dust(CKD"); J. American Sci., 6 (12), 910-917, 2010.

[12] Vasu, A. E.; "Surface modification of activated carbon for enhancement of nickel(II) adsorption"; Electronic J. Chem., 5 (4), 814-819, 2008 .

[13] Kadirvelu, K.; Namasivayam, C.; "Activated carbon from coconut coirpith as metal adsorbent: adsorption of Cd(II) from aqueous solution"; Advance Environ. Res., 7, 471-478, 2003.

[14] Moreno, J.C.; Gomez, R.; Giraldo, L.; "Removal of $\mathrm{Mn}, \mathrm{Fe}, \mathrm{Ni}$ and $\mathrm{Cu}$ ions from wastewater using cow bon charcoal"; Materials, 3, 452-466, 2010.

[15] Jarullah, A. A.; Alias, M. F.; Hassan, K.H.; "Removal of nickel(II) from aqueous solution using activated charcoal derived from the leaves of bitter orange tree (Citrus aurantium)"; Accepted for publication in J. Chemistry and Chemical Eng., 2012.

[16] Onundi, Y. B.; Mamun, A. A.; Alkhatib, M. F.; Ahmed, Y. M.; "Adsorption of copper, nickel and lead ions from synthetic semiconductor industrial wastewater by palm shell activated carbon"; Int. J. Environ. Sci. Tech., 7 (4), 751-758, 2010.

[17] Babarinde, N.A.A.; Babalola, J.O.; Adegboye, K.A.; "Kinetic, isotherm and thermodynamic studies of the biosorption of cadmium(II) by snail (lymnaea rufescens) shell"; J. Appl. Sci. Res., 4 (11), 1420-1427, 2008.
[18] Babarinde, N.A.A.; Babalola, J.O.; Olukanni, O.; "Thermodynamic and isotherm studies of the biosorption of cadmium (II) from solution by maize wrapper", Int. J. Phys. Sci., 3(3), 071-074, 2008 .

[19] Goel, J.; Kadirvelue, K.; Rajagopal, C.; Garg, K.; "Investigation of adsorption of lead, mercury and nickel from aqueous solutions onto carbon aerogel"; J. Chem. Technol. Biotechnol., 80, 469-476, 2005

[20] Kumar, P.S.; Kirthika, K.; "Equilibrium and kinetic study of adsorption of nickel from aqueous solution onto bael tree leaf powder"; J. Eng. Sci. Tech., 4 (4), 351363, 2009.

[21] Liang, S.; Guo, X.; Feng, N.; Tian, Q.; "Isotherms, Kinetics and thermodynamic studies of adsorption of $\mathrm{Cu}^{2+}$ from aqueous solutions by $\mathrm{Mg}^{2+} / \mathrm{K}^{+}$type orange pell adsorbents"; J. Hazardous Materials, 174, 756-762, 2010 .

[22] Alberty, R.A.; "Physical chemistry"; John Wiley and Sons, New York, $7^{\text {th }}$ ed., 1987.

[23] Meisslamawy, H.A.J.; "Sorption capacity measurement of sulphuric acid in the active mass of the Iraq lead acid storage battery"; M.Sc. thesis, College of Science for Women-University of Baghdad, Iraq, 2006 .

[24] Aksu, Z.; Donmez, G.; "Binary biosorption of cadmium(II) and $\mathrm{Ni}$ (II) onto dried chlorella vulgaris: Co-ion effect on mono-component isotherm parameters"; Process Biochemistry, 41, 860-868, 2006.

[25] Laidler, K.J.; Meiser, J.H.; "Physical chemistry"; Benjamin Cummings Puplishing Company, California, 1982.

[26] Goel, A.; "Surface chemistry", Discovery Publishing House, India, $1^{\text {st }}$ ed, 2006.

[27] Nomanbhay, S. M.; Palanisamy, K.; "Removal of heavy metal from industrial wastewater using chitosan coated oil palm shell charcoal"; Electronic J. Biotech., 8 (1) , 43-53, 2005. 
يتتاول البحث تتقية المحلول المائي من ايون النيكل

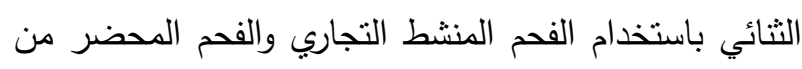
اوراق النارنج كسطوح امتزاز ودراسة زمن التماس بين المادة الممتزة وسطحي الامتزاز عند درجة حرارة هوب كلفن والدالة الحامضية ه حيث بينت نتائج الدراسة ان النسبة المئوية

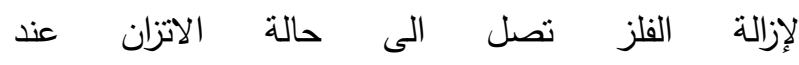
Vo دقيقة على سطح الفحم التجاري و • 9 دقيقة على سطح

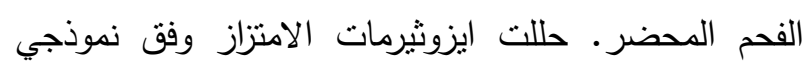

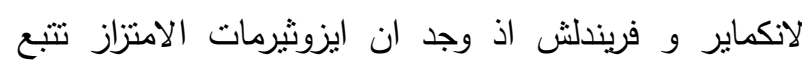
معادلة لانكماير • كما تضمن البحث دراسة حركية لإمتزاز

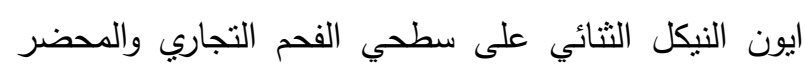
بتطبيق معادلات المرتبة الاولى والثانية حيث اظهرت النتائج

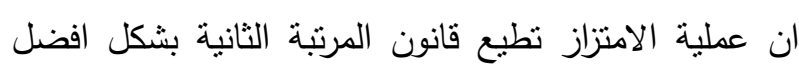
وبمعامل ارتباط 0.9992 للفحم التجاري و 0.9974 للفحم المحضر من اوراق النارنج.

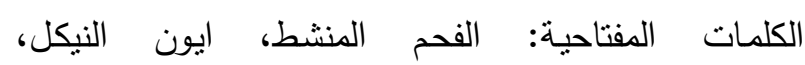
لانكمايرايزوثيرم، فريندلش ايزوثيرم. 